\title{
EVROPSKÁ LEGISLATIVA A ZELENÉ STŘECHY
}

\section{EUROPEAN LEGISLATION AND GREEN ROOFS}

\author{
Lukáš Bř́za*,1
}

\author{
Llukas.Briza@vut.cz \\ ${ }^{1}$ Vysoké učení technické v Brně, Fakulta stavební, Ústav technologie, mechanizace a řízení staveb, Veveří 331/95, 60200 Brno, Česká \\ republika
}

\begin{abstract}
Abstrakt
Důležitou součástí procesu navrhování a realizování staveb jsou různá nařízení, normy, regulativy či doporučení. Má-li stavební inženýr navrhnout a realizovat stavební konstrukci, musí se těchto nařízení pevně držet. Je tak zaručeno, že výsledná konstrukce bude mít potřebné vlastnosti a bude splňovat podmínky pro uživání, stejně tak jako bude ekonomicky, sociálně a environmentálně vyvážená. Čím specifičtěji a důsledněji jsou tyto nařízení zpracovány, tím lepších výsledků může být dosaženo.

V tomto př́spěvku bude zhodnocena současnou legislativní situace v České republice a vybraných Evropských státech ve vztahu k zeleným střechám. Ty, jakožto nastupující konstrukce budoucnosti, nejsou prozatím v normách tak pevně zakotveny. A to i přesto, že si to vyžaduje nejen budoucí důležitost zelených konstrukcí, ale tak i jejich významná historie.
\end{abstract}

\section{Klíčová slova}

Zelená střecha, vegetační stř̌echa, legislativa, normy, Evropa, Česká republika, porovnání

\begin{abstract}
Various regulations, standards, regulations or recommendations are an important part of the design and construction process. If a civil engineer is to design and construct a building construction, he must adhere to these regulations firmly. This ensures that the resulting construction will have the necessary characteristics and meet the conditions of use, as well as be economically, socially and environmentally balanced. The more specific and consistent these regulations are, the better the results can be achieved.

This paper will evaluate the current legislative situation in the Czech Republic and selected European countries in relation to green roofs. These, as the emerging constructions of the future, are not so firmly anchored in the standards. This is despite the fact that it requires not only the future importance of green structures, but also their important history.
\end{abstract}

\section{Key words}

Green roof, vegetation roof, legislative, standard, Europe, the Czech Republic, comparison

\section{1 ÚVOD}

Z hlediska různých vlivů, at' už změny klimatu či čím dál tím vyšší potřebě po zelených plochách v hustě zastavěných oblastech je důležitá podpora rozvoje zelených střech. Z mnohých př́padových i obecných studií a zkoumání již známe důležitost významu těch zelených střech, které je netřeba více zdůvodňovat. A proto je důležitým předpokladem pro jejich podporu kvalitní legislativní a normativní prostředí. "V České republice jsou na rozdíl od některých jiných evropských zemí zelené střechy v legislativě zmiňovány pouze okrajově, ale české zákony vytváření vesměs otevřené prostředí pro jejich širší uplatnění." [1]. 


\section{2 ČESKÁ LEGISLATIVA VE VZTAHU K ZELENÝM STŘECHÁM}

Regulace výstavby a rozvoje území je v České republice naplňována na základě územního plánování, které se řídí zákonem č. 183/2006 Sb., o územním plánování a stavebním řádu (stavební zákon). Dalšími, z hlediska vztahu k zeleným střechám, jsou zajímavé zákony: zákon č. 114/1992 Sb., o ochraně př́rody a krajiny, zákon č. 254/2001 Sb., o vodách a o změně některých zákonů (vodní zákon), vyhláška č. 269/2009 Sb., kterou se mění vyhláška č. 501/2006 Sb., o obecných požadavcích na využívání území či zákon č. 274/2001 Sb., o vodovodech a kanalizacích a vyhláška č. 428/2001 Sb. Z norem je pak významná norma ČSN 730540 Tepelná ochrana budov. Z mimo legislativních předpisů fungují Standardy pro navrhování, provádění a údržbu vegetačních souvrství zelených střech.

\section{Zákon č. 183/2006 Sb., o územním plánování a stavebním řádu (stavební zákon)}

Tento dokument je základním nástrojem státní správy a má tak rozhodující vliv na výstavbu v České republice. Svým rozsahem a přesahem ovšem neumožňuje detailněji se věnovat tak úzké oblasti, jako představují zelené stř̌echy. Zákon svým zněním ponechává široké manipulační pole jednotlivých stavebním úřadům v oblasti výkladu předpisů. Je tak na každém jednom pracovníkovi státní správy, aby zohlednil pozitivní vliv zelených střech v oblastech dotčených Stavebním zákonem. Jedná se o oblast snižování rizika lokálních povodní, zabraňování přehřivání okolí budov, vlivu staveb na životní prostředí či udržitelnost výstavby.

\section{Zákon č. 114/1992 Sb., o ochraně přírody a krajiny}

Smyslem tohoto zákona je, jak již jeho název napovídá, chránit přírodu a přírodní krajinu. Ze stavebního hlediska je v tomto zákoně zajímavá možnost uložit stavebníkovi kompenzační povinnost. Ta se v současné době bohužel týká pouze kácení a následné výsadby dřevin. Z hlediska povinnosti realizace zelených střech nebo náhrady ztracených zelených ploch vlivem výstavby má tento zákon mezery.

\section{Zákon č. 254/2001 Sb., o vodách a o změně některých zákonů (vodní zákon)}

Vodní zákon se mimo jiné zabývá zadržováním vody v krajině. Přičemž víme, že zelené střechy mohou významně přispět ke schopnosti konstrukce zadržovat srážkové vody v místě jejich spadu. Při vhodném výkladu § 102 článku 1) a 2) lze za předpokladu prokázání veřejného zájmu a opodstatnění zelené střechy pracovat s možností uhrazení výdajů na opatření zelené střechy. V rámci Vodního zákona se tedy dá hovořit o př́mé finanční podpoře zelených střech.

$\S 102$ Zákona č. 254/2001 Sb.:

1) Stát může poskytnout finanční prostředky $k$ úhradě výdajů na opatření ve veřejném zájmu, zejména pro p) vsakování, zadržováni a odváděni srážkových vod.

2) Finanční prostředky na opatřeni ve veřejném zájmu poskytuje stát správcům povodí, České inspekci životniho prostředí, správcům vodnich toki̊, vlastnikưm vodních děl a pověreným odborným subjekti̊m (\$21 odst. 3) a jiným fyzickým a právnickým osobám na finanční prostředky není právní nárok [2].

\section{Dotační program Zeleň stř̌echám!}

V roce 2019 schválilo zastupitelstvo města Brna jako první v České republice dotační program na podporu vytváření zelených střech. Jak je uvedeno v oficiální výzvě Odboru životního prostředí MMB: “Cílem programu je aktivní iniciační podpora statutárního města Brna (dále jen "SMB”) v oblasti šetrné trvale udržitelné výstavby s nízkou uhlíkovou stopou a významným retenčním prvkem ve formě vegetačních konstrukcí.” [3]. Dále odůvodňují význam zelených střech jejich jednoduchou instalací, adaptací na současné projekty a pozitivním vnímáním vegetačních střech žadateli o dotaci.

Dotaci mohou získat jak fyzické osoby (Skupina žadatelů A) tak i právnické osoby (skupina žadatelů B). Dotační program poskytuje rozdílné prostředky pro instalací intenzivní zelené střechy nebo extenzivní zelené střechy, prričemž u extenzivních střech rozlišuje ještě mezi rozchodníkovými koberci a sazenicemi a řízky rozchodníků. 


\section{Standardy pro navrhování, provádění a údržbu vegetačních souvrství zelených střech}

Technické normy ČSN 731901 (navrhování střech - základní ustanovení), TNV 959011 (Hospodaření se srážkovými vodami), ČSN 756760 (Vnitřní kanalizace), ČSN 730540 (tepelná ochrana budov) apod. pojednávají o zelených střechách jen okrajově a zcela stroze. Vlastní normativní prostředí zelené střechy v České republice nemají. Jediným dokumentem, který tedy zcela jasně definuje pojmy zelených střech, definuje jejich funkci, rozlišuje jejich konstrukční řešení a předkládá možné hodnotící parametry je v současné době publikace Standardy pro navrhování, provádění a údržbu - vegetační souvrství zelených střech. Tyto standardy se inspirují v zahraničních publikacích a vychází např́klad ze švýcarské normy SIA 312, rakouské normy Ö-NORM B 2501, britské GRO Code nebo z mezinárodní směrnice FLL, kterou používají např́iklad v Německu.

\section{EVROPSKÁ LEGISLATIVA VE VZTAHU K ZELENÝM STŘECHÁM}

Při pátrání po zelených střechách v evropských legislativách jsme se zaměřili především na to, jak jsou zelené střechy zakotveny v legislativě, zda mají podporu i v jiných, nelegislativních dokumentech nebo zda mají své finanční podpůrné programy. Odpovědi na níže uvedené otázky jsme získali z Francie, Itálie a Nizozemí.

\section{Francouzská legislativa a zelené střechy}

Zelené střechy mají ve Francii své legislativní místo dobře zakotvené v normách. Konkrétně jsou obsaženy v Norme NF-DTU 43.1, Norme NF-DTU 43.3 a Norme NF-DTU 43.4. Zároveň existuje podpůrný dokument, který stojí mimo legislativní a normové prostředí. Jsou jím Pravidla pro návrh a provádění zelených střech dle ADIVET (Association of roots and green fronts).

Přestože ve Francii pravděpodobně neexistují žádné právní předpisy nařizující výstavbu zelených střech, jsou zelené střechy relativně dobře podporovány. Jednotlivé podpůrné programy jsou řešeny převážně regionálně nebo na městské úrovni (např. Paříž nebo Lille). Tyto lokální programy poskytují at' už finanční podporu na výstavbu zelených střech, nebo podporu v podobě daňových úlev.

\section{Italská legislativa a zelené střechy}

Italská legislativní podpora zelených střech není tak široce pojatá, jako ve Francií, přesto ovšem existuje. Podpůrným normativním dokumentem je UNI 11235. Mimo tuto normu ovšem žádný nelegislativní dokument zřejmě neexistuje.

Zákony v žádné oblasti výstavby v Itálii také nenařizují realizaci zelených střech. Přesto mohou být vlastnící soukromých domů se zelenou střechou zvýhodněni na daních, př́padně různými jinými benefity v případě bytové výstavby. Tyto výhody se ale mohou lišit napříc Itálií, kde např́iklad autonomní oblast Bolzano v Jižním Tyrolsku má své mimo italské úpravy zákonů.

\section{Nizozemská legislativa a zelené střechy}

Nizozemská legislativa, podle námi ověřených zdrojů, v globálním měřítku zatím neobsahuje samostatné zákony či normy pro zelené střechy. Stejně jsou na tom v Nizozemí i se státem negarantovanými, nezastřešenými dokumenty. Přesto se v zákonech objevují odkazy na vegetační konstrukce. Př́kladem může být požární norma, která předkládá $50 \mathrm{~cm}$ ochranné pásmo na okraji střechy bez vegetace.

Přestože stát neřeší legislativně zelené střechy samostatně a neukládá žádnou povinnost jejich výstavby, jsou zelené střechy často zakotveny v městských vyhláškách a regulacích. Téměř každé větší město má svůj vlastní dokument (např. Rotterdam, Amsterdam), jímž řeší výstavbu zelených střech na jejich území. Zároveň dochází $\mathrm{k}$ pozitivní motivaci formou různých finančních benefitů a úlev. 


\section{SROVNÁNÍ ČESKÉ LEGISLATIVY A LEGISLATIVY VYBRANÝCH EVROPSKÝCH STÁTŮ VE VZTAHU K ZELENÝM STŘECHÁM}

Při porovnávání současné české legislativy s legislativou evropskou, respektive s legislativou vybraných evropských zemí, sledujeme především měřítka:

- zda má vybraná země státem garantovanou normu či předpis pro vegetační konstrukce

- zda má vybraná země státem negarantovanou normu či předpis pro vegetační konstrukce

- a zda existují lokální, městské výjimky

Sestavili jsme pro to dotazník obsahující 7 otázek. Tyto otázky včetně přehledu odpovědí jsou uvedeny v následující Tab. 1.

Tab. 1 Porovnání české a evropské legislativy ve vztahu k zeleným střechám.

\begin{tabular}{lllll}
\hline$C Z$ & FR & IT & $N L$ \\
\hline
\end{tabular}

Existuje státem garantovaná národní norma či předpis pro návrh a provádění vegetačních konstrukcí?

NE ANO ANO NE

Existuje jiná, státem negarantovaná norma či předpis pro návrh a provádění vegetačních konstrukcí?

\begin{tabular}{cccc}
\hline ANO & ANO & NE \\
\hline Řeší požární norma vegetační konstrukce? Pokud ano, jak? & \\
\hline ANO & NE & NE & ANO \\
\hline
\end{tabular}

Existuje finanční dotace jako podpora pro výstavbu vegetačních konstrukcí?

\begin{tabular}{lccc}
\hline NE & ANO & ANO & ANO \\
\hline \multicolumn{2}{c}{ Vyplývá z nějakého předpisu povinnost pro výstavbu vegetačních konstrukcí? } & NE & NE \\
\hline NE & NE & ANO \\
\hline Existují nějaké, např́klad finanční, úlevy pro vlastníky budov s vegetačními konstrukcemi? \\
\hline NE & ANO & ANO \\
\hline Existují regionální, či městské výjimky pro vše výše uvedené? Pokud ano, jaké a kde? \\
\hline ANO ANO & ANO & ANO
\end{tabular}




\section{ZÁVĚR}

Ze získaných dat je zřejmé, že začlenění vegetačních konstrukcí do evropských legislativních dokumentů není prríliš obvyklé. Úprava předpisů a podpưrných programů se řeší především na regionální úrovni a v rámci městských vyhlášek. Vzhledem ke geografickým odlišnostem se jedná zřejmě o správný model.

V porovnání s jinými evropskými státy Česká republika spíše pokulhává, než že by držela krok či dokonce stanovovala tempo. Nicméně i zde už se začínají objevovat první, avšak stále ojedinělé, programy na podporu trvale udržitelné výstavby skrze vegetační konstrukce. Pozitivním příkladem je v tomto př́padě město Brno. Do budoucna je však rozhodně nutné, aby došlo k rozšiření tohoto úkazu na více místech České republiky.

\section{Poděkování}

Článek vznikl v rámci řešení juniorského specifického výzkumu č. FAST-J-19-5867 "Možnosti prefabrikace zelených střech".

\section{Použité zdroje}

[1] DOSTÁL, Pavel, Jan MACHAČ, Lenka DUBOVÁ a Jiř́i LOUDA. Způsoby systémové podpory výstavby zelených střech. Brno: Svaz zakládání a údržby zeleně, Odbor sekce Zelené stř̌echy, 2017.

[1] Zákon č. 254/2001 Sb., o vodách a o změně některých zákonů (vodní zákon).

[2] STATUTÁRNÍ MĚSTO BRNO - Odbor životního prostředí MMB. Program: Podpora vytvárení zelených střech. Brno: Zastupitelstvo města, 2019. 